\title{
Pengaruh Moral Wajib Pajak, Penghindaran Pajak, Sanksi Perpajakan, dan Sikap Wajib Pajak terhadap Kepatuhan Wajib Pajak Orang Pribadi di Kantor Pelayanan Pajak Pratama Palembang Seberang Ulu
}

\author{
Mursalin \\ Manajemen, F.Ekonomi dan Bisnis, Univ.PGRI Palembang, mursalin@univpgri-palembang.ac.id
}

\begin{abstract}
ABSTRAK
Penelitian ini bertujuan untuk mengetahui pengaruh Moral Wajib Pajak, Penghindaran Pajak, Sanksi Perpajakan, dan Sikap Wajib Pajak terhadap Kepatuhan Wajib Pajak Orang Pribadi di Kantor Pelayanan Pajak Pratama Palembang Seberang Ulu. Hasil penelitian ini menunjukkan secara parsial masing-masing bahwa Moral Wajib Pajak tidak berpengaruh terhadap Kepatuhan Wajib Pajak Orang Pribadi. Penghindaran Pajak tidak berpengaruh terhadap Kepatuhan Wajib Pajak Orang Pribadi. Sanksi Perpajakan berpengaruh terhadap Kepatuhan Wajib Pajak Orang Pribadi. Sikap Wajib Pajak berpengaruh terhadap Kepatuhan Wajib Pajak Orang Pribadi. Secara simultan Moral Wajib Pajak, Penghindaran Pajak, Sanksi Perpajakan, dan Sikap Wajib Pajak berpengaruh terhadap Kepatuhan Wajib Pajak Orang Pribadi. Berdasarkan kesimpulan penelitian ini maka Wajib Pajak memiliki moral yang baik dalam memiliki NPWP dan jujur dalam melaporkan SPT, Wajib Pajak taat dalam membayar pajak sehingga akan terhindar dari sanksi perpajakan, Wajib Pajak menaati semua peraturan perpajakan yang berlaku, dan Wajib Pajak tepat waktu dalam memenuhi semua kewajiban perpajakan dan hak perpajakannya.
\end{abstract}

Kata kunci : Moral Wajib Pajak, Penghindaran Pajak, Sanksi Perpajakan, Sikap Wajib Pajak, Kepatuhan Wajib Pajak Orang Pribadi.

\begin{abstract}
This study aims to determine the effect of taxpayers' morals, tax avoidance, tax sanctions and taxpayer attitudes towards individual taxpayer compliance at the Palembang Seberang Ulu Pratama Tax Office. The results of this study indicate partially each of the Taxpayers' Moral has no effect on Individual Taxpayer Compliance. Tax Avoidance has no effect on Individual Taxpayer Compliance. Tax Sanctions affect Individual Taxpayer Compliance. The attitude of the Taxpayer has an effect on Individual Taxpayer Compliance. Simultaneously, Taxpayer Morals, Tax Avoidance, Tax Sanctions and Taxpayer Attitudes affect Individual Taxpayer Compliance. Based on the conclusions of this study, taxpayers have good morals in having an NPWP and are honest in reporting SPT, taxpayers are obedient in paying taxes so that they will avoid tax sanctions, taxpayers obey all applicable tax regulations, and taxpayers are on time to fulfill all tax obligations and tax rights.
\end{abstract}

Keywords: Taxpayer Morals, Tax Avoidance, Tax Sanctions, Taxpayer Attitudes, Personal Taxpayer Compliance.

\section{A. PENDAHULUAN}

Pengertian Pajak menurut Undang-undang Nomor 16 Tahun 2009 Pasal 1 adalah kontribusi wajib kepada negara yang terutang oleh orang pribadi atau badan yang bersifat memaksa berdasarkan undangundang dengan tidak mendapatkan imbalan secara langsung dan digunakan untuk keperluan negara bagi sebesar-besarnya kemakmuran rakyat.

Permasalahan yang sering terjadi berkaitan dengan pemungutan pajak yaitu masih banyaknya masyarakat yang tidak mau memenuhi kewajiban pajaknya. Menurut Rahayu (2017: 192) kepatuhan Wajib Pajak menjadi aspek yang paling penting mengingat bahwa sistem perpajakan di Indonesia

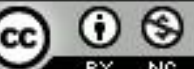


menuntut Wajib Pajak untuk turut aktif dalam pemenuhan kewajiban perpajakannya. Sistem pemungutan yang berlaku adalah sistem Self Assesment System, dimana segala pemenuhan kewajiban perpajakan dilakukan sepenuhnya oleh Wajib Pajak, fiskus hanya melakukan pengawasan melalui prosedur penelitian.

Kepatuhan Wajib Pajak sangat dipengaruhi oleh moralitas dari Wajib Pajak. Hal ini disebabkan karena membayar pajak adalah suatu aktivitas yang tidak lepas dari kondisi moral reasoning itu sendiri. Aspek moral dalam bidang perpajakan menyangkut dua hal, yaitu (1) kewajiban perpajakan merupakan kewajiban moral yang harus ditunaikan oleh setiap Wajib Pajak, dan (2) menyangkut kesadaran moral terkait dengan alokasi atau distribusi dari penerimaan pajak (Heru, 2019: 263).

Penghindaran pajak merupakan salah satu upaya meminimalisasi beban pajak yang sering dilakukan oleh Wajib Pajak, karena masih berada dalam peraturan perpajakan yang berlaku dengan memanfaatkan ketentuan-ketentuan dibidang perpajakan. Di sisi lain penghindaran pajak ini menyebabkan permintaan barang yang dikenakan pajak menjadi berkurang, atau bertambahnya permintaan barang lain sekaligus terjadi penambahan dalam produksi barang yang tidak dikenakan pajak berat, tetapi dapat meningkatkan tabungan atau investasi lain (Rahayu, 2017: 202).
Persepsi Wajib Pajak mengenai sanksi perpajakan adalah faktor penting dalam menentukan kepatuhan Wajib Pajak dalam memenuhi semua kewajiban pajakanya. Sejauh ini sanksi pajak digunakan untuk meningkatkan kepatuhan Wajib Pajak membayar pajaknya. Masyarakat pada umumnya patuh pada peraturan apabila ada sanksi yang mengikat. Semakin tinggi sanksi yang diberikan, maka menghasilkan kepatuhan yang semakin semakin baik.

Sikap Wajib Pajak merupakan pernyataan atau pertimbangan evaluatif, baik menguntungkan atau tak menguntungkan mengenai obyek, orang atau peristiwa. Sikap Wajib Pajak mencerminkan bagaimana Sikap Wajib Pajak terhadap aspek lingkungan pajak baik sikapnya terhadap peraturan pajak, kebijakan pajak, adminitrasi pajak dan pelayanan pajak. Sikap yang baik dari Wajib Pajak meningkatkan kecenderungan kepatuhan dari Wajib Pajak (Heru, 2019: 264).

Sebagai salah satu Kantor Pelayanan Pajak di Kota Palembang, Kantor Pelayanan Pajak Pratama Palembang Seberang Ulu mengalami peningkatan jumlah Wajib Pajak orang pribadi yang terdaftar, tetapi tingkat kepatuhan Wajib Pajak orang pribadi masih rendah. Dilihat dari data jumlah Wajib Pajak orang pribadi yang terdaftar dari jumlah Wajib Pajak orang pribadi yang wajib menyampaikan SPT di KPP Pratama Palembang Seberang Ulu dalam tabel berikut ini: 


\section{Tabel Tingkat Kepatuhan Wajib Pajak Orang Pribadi Kantor Pelayanan Pajak Pratama Palembang Seberang Ulu Tahun 2015-2019}

\begin{tabular}{|c|c|c|c|}
\hline Tahun & $\begin{array}{c}\text { Jumlah WP OP } \\
\text { Terdaftar }\end{array}$ & $\begin{array}{c}\text { Jumlah WP OP } \\
\text { Menyerahkan SPT }\end{array}$ & $\begin{array}{c}\text { Persentase Kepatuhan } \\
\text { WP OP (\%) }\end{array}$ \\
\hline 2015 & 48.462 & 36.312 & 74,92 \\
\hline 2016 & 53.857 & 38.223 & 70,97 \\
\hline 2017 & 58.627 & 28.024 & 47,80 \\
\hline 2018 & 53.673 & 30.741 & 57,27 \\
\hline 2019 & 62.694 & 36.404 & 58,06 \\
\hline
\end{tabular}

\section{Sumber: KPP Pratama Palembang Seberang Ulu (2020)}

Berdasarkan tabel di atas menunjukkan bahwa meningkatnya jumlah Wajib Pajak Orang Pribadi yang terdaftar belum tentu menunjukkan peningkatan Kepatuhan Wajib Pajak Orang Pribadi. Di lihat dari Wajib Pajak Orang Pribadi yang terdaftar dari tahun 2015 sampai dengan tahun 2017 mengalami kenaikan setiap tahunnya tetapi tahun 2018 Wajib Pajak Orang Pribadi yang terdaftar mengalami penurunan sebanyak 4.945 orang dan tahun 2019 bertambah sebanyak 10.124 orang. Namun penambahan tersebut tidak terjadi pada Wajib Pajak Orang Pribadi yang menyampaikan SPT tahun 2015 sebanyak 36.312 orang, tahun 2016 sebanyak 38.223 orang dan mengalami kenaikan sebanyak 1.911 orang, tahun 2017 sebanyak 28.024 orang dan mengalami penurunan sebanyak 10.199 orang, tahun 2018 sebanyak 30.741 orang dan mengalami kenaikan sebanyak 2.717 orang, tahun 2019 sebanyak 36.404 orang dan mengalami kenaikan sebanyak 5.663 orang. Hal ini berdampak pada tingkat kepatuhan WP OP di KPP Pratama Palembang Seberang Ulu itu sendiri. Jika dilihat dari tahun 2015-2017, tingkat kepatuhan WP OP sebanyak $74,92 \%$, namun turun menjadi $70,97 \%$ di tahun 2016, pada tahun 2017 menurun lagi menjadi $47,80 \%$, pada tahun 2018 sebanyak $57,27 \%$ dan mengalami peningkatan sebanyak
9.047 orang, pada tahun 2019 sebanyak 58,06\% dan mengalami peningkatan tidak signifikan menjadi 79 orang.

Ini menandakan bahwa tingkat kepatuhan Wajib Pajak orang pribadi di KPP Pratama Palembang Seberang Ulu masih rendah, dimana hanya setengah dari jumlah Wajib Pajak orang pribadi yang melaksanakan kepatuhan Wajib Pajak orang pribadi dengan baik. Banyak faktor yang menyebabkan Wajib Pajak yang tidak melaksanakan kewajiban perpajakan salah satunya masalah Moral Wajib Pajak, Penghindaran Pajak, Sanksi Perpajakan dan Sikap Wajib Pajak dan masih banyak Wajib Pajak yang tidak melaksanakan hak dan kewajibannya dengan baik.

Berdasarkan uraian di atas, penulis tertarik melakukan penelitian yang berjudul "Pengaruh Moral Wajib Pajak, Penghindaran Pajak, Sanksi Perpajakan, dan Sikap Wajib Pajak terhadap Kepatuhan Wajib Pajak Orang Pribadi di Kantor Pelayanan Pajak Pratama Palembang Seberang Ulu."

\section{B. KAJIAN TEORI}

Heru (2019: 263) Teori Perkembangan Moral (Theory of Moral Reasoning) adalah teori yang menyatakan keputusan moral terutama yang dipengaruhi oleh perlakuan terhadap sanksi pada tingkatan moral 
reasoning yang rendah, pengharapan akan adanya keadilan (peer expectation) pada tingkatan yang tertinggi. Wajib Pajak yang menggunakan prinsip moral dalam pengambilan keputusan pembayaran pajak akan lebih patuh dibandingkan Wajib Pajak lainnya. Wajib Pajak dengan tingkatan moral yang sama tetapi memiliki persepsi yang berbeda akan memilki reaksi yang berbeda terhadap kepatuhan pajak.

Heru (2019: 264) teori ekuitas yang menekankan pada aspek keadilan. Teori ini menyangkut aspek hak dan kewajiban Wajib Pajak. Apabila Wajib Pajak memandang bahwa hak dan kewajibannya sebanding dengan artian bahwa adanya keseimbangan antara kewajibannya sebagai Wajib Pajak dan hak-hak yang dapat diperolehnya, maka Wajib Pajak cenderung lebih patuh dalam menjalankan kewajiban pajaknya. Teori ini juga menyangkut keadilan dalam perlakuan terhadap setiap Wajib Pajak.

\section{Mardiasmo}

(2016:

menyatakan Wajib Pajak adalah orang pribadi atau badan, meliputi pembayaran pajak, pemotong pajak dan pemungut pajak, yang mempunyai hak dan kewajiban perpajakan sesuai dengan ketentuan peraturan perundang-undangan perpajakan. Sedangkan Resmi (2016: 27) menyatakan Wajib Pajak adalah orang pribadi atau badan, meliputi pembayaran pajak, pemotong pajak dan pemungut pajak, yang mempunyai hak dan kewajiban perpajakan sesuai dengan ketentuan peraturan perundang-undangan perpajakan.

\section{Kerangka Pemikiran}

\section{Gambar Kerangka Pemikiran}

\section{Pengaruh Moral Wajib Pajak, Penghindaran Pajak, Sanksi Perpajakan dan} Sikap Wajib Pajak terhadap Kepatuhan Wajib Pajak Orang Pribadi

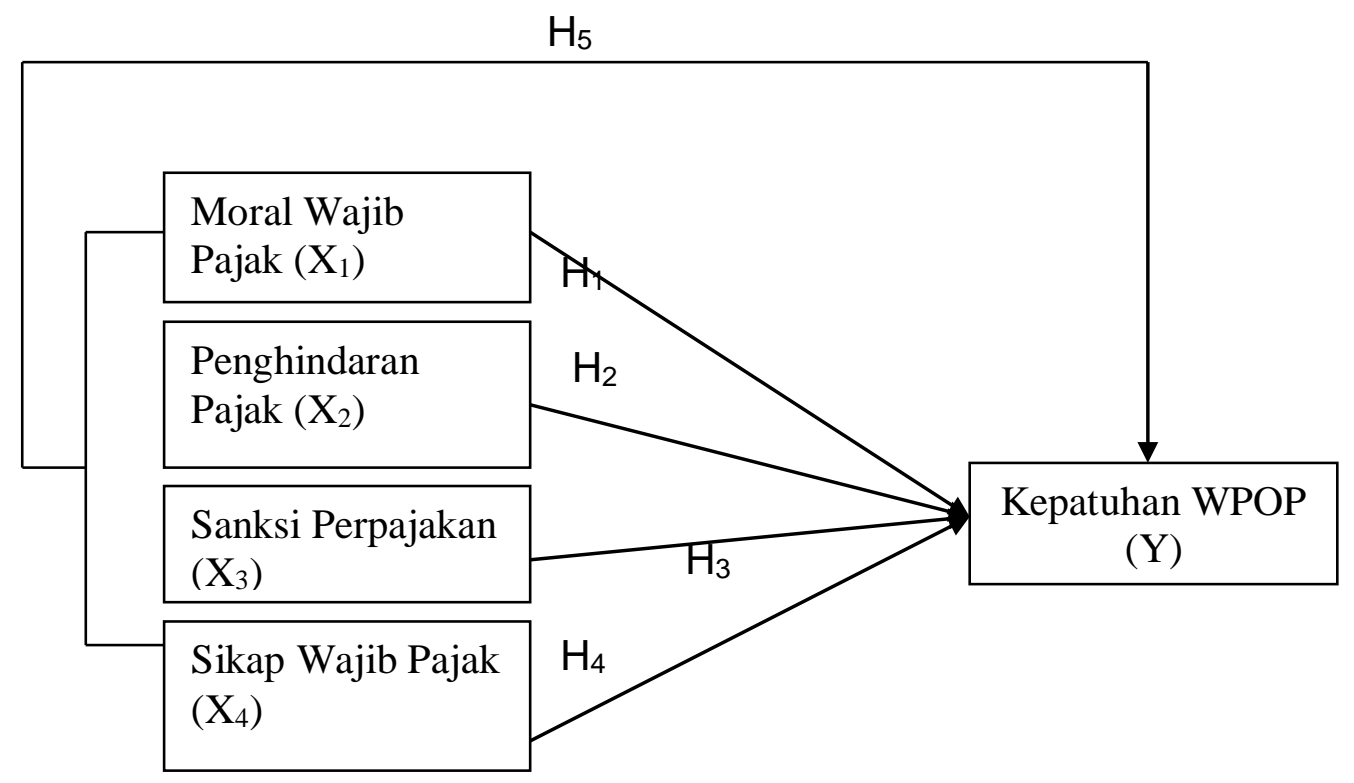




\section{Pengembangan Hipotesis}

Pengaruh Moral Wajib Pajak terhadap Kepatuhan Wajib Pajak Orang Pribadi

Kepatuhan Wajib Pajak sangat dipengaruhi oleh moralitas dari Wajib Pajak. Hal ini disebabkan karena membayar pajak adalah suatu aktivitas yang tidak lepas dari kondisi moral reasoning itu sendiri. Aspek moral dalam bidang perpajakan menyangkut dua hal, yaitu (1) kewajiban perpajakan merupakan kewajiban moral yang harus ditunaikan oleh setiap Wajib Pajak, dan (2) menyangkut kesadaran moral terkait dengan alokasi atau distribusi dari penerimaan pajak (Heru, 2019: 263).

\section{$\mathrm{H}_{1}$ : Pengaruh Moral Wajib Pajak} terhadap Kepatuhan Wajib Pajak Orang Pribadi

\section{Pengaruh Penghindaran Pajak terhadap Kepatuhan Wajib Pajak Orang Pribadi}

Penghindaran pajak merupakan salah satu upaya meminimalisasi beban pajak yang sering dilakukan oleh Wajib Pajak, karena masih berada dalam peraturan perpajakan yang berlaku dengan memanfaatkan ketentuan-ketentuan dibidang perpajakan. Di sisi lain penghindaran pajak ini menyebabkan permintaan barang yang dikenakan pajak menjadi berkurang, atau bertambahnya permintaan barang lain sekaligus terjadi penambahan dalam produksi barang yang tidak dikenakan pajak berat, tetapi dapat meningkatkan tabungan atau investasi lain (Rahayu, 2017: 202).

\section{$\mathrm{H}_{2}$ : Pengaruh Penghindaran Pajak terhadap Kepatuhan Wajib Pajak Orang Pribadi}

\section{Pengaruh Sanksi Perpajakan terhadap Kepatuhan Wajib Pajak Orang Pribadi}

Persepsi Wajib Pajak mengenai sanksi perpajakan adalah faktor penting dalam menentukan kepatuhan Wajib Pajak dalam memenuhi semua kewajiban pajakanya. Sejauh ini sanksi pajak digunakan untuk meningkatkan kepatuhan Wajib Pajak membayar pajaknya. Masyarakat pada umumnya patuh pada peraturan apabila ada sanksi yang mengikat. Semakin tinggi sanksi yang diberikan, maka menghasilkan kepatuhan yang semakin semakin baik.

$\mathrm{H}_{3}$ : Pengaruh Sanksi Perpajakan terhadap Kepatuhan Wajib Pajak Orang Pribadi

\section{Pengaruh Sikap Wajib Pajak terhadap Kepatuhan Wajib Pajak Orang Pribadi}

Sikap Wajib Pajak merupakan pernyataan atau pertimbangan evaluatif, baik menguntungkan atau tak menguntungkan mengenai obyek, orang atau peristiwa. Sikap Wajib Pajak mencerminkan bagaimana Sikap Wajib Pajak terhadap aspek lingkungan pajak baik sikapnya terhadap peraturan pajak, kebijakan pajak, adminitrasi pajak dan pelayanan pajak. Sikap yang baik dari Wajib Pajak meningkatkan kecenderungan kepatuhan dari Wajib Pajak (Heru, 2019: 264).

$\mathrm{H}_{4}$ : Pengaruh Sikap Wajib Pajak terhadap Kepatuhan Wajib Pajak Orang Pribadi

Pengaruh Moral Wajib Pajak, Penghindaran Pajak, Sanksi Perpajakan dan Sikap Wajib Pajak Secara Bersama-sama terhadap Kepatuhan Wajib Pajak Orang Pribadi 
Kepatuhan Wajib Pajak sangat dipengaruhi oleh moralitas dari Wajib Pajak. Hal ini disebabkan karena membayar pajak adalah suatu aktivitas yang tidak lepas dari kondisi moral reasoning itu sendiri. Aspek moral dalam bidang perpajakan menyangkut dua hal, yaitu (1) kewajiban perpajakan merupakan kewajiban moral yang harus ditunaikan oleh setiap Wajib Pajak, dan (2) menyangkut kesadaran moral terkait dengan alokasi atau distribusi dari penerimaan pajak (Heru, 2019: 263).

Penghindaran pajak merupakan salah satu upaya meminimalisasi beban pajak yang sering dilakukan oleh Wajib Pajak, karena masih berada dalam peraturan perpajakan yang berlaku dengan memanfaatkan ketentuan-ketentuan dibidang perpajakan. Di sisi lain penghindaran pajak ini menyebabkan permintaan barang yang dikenakan pajak menjadi berkurang, atau bertambahnya permintaan barang lain sekaligus terjadi penambahan dalam produksi barang yang tidak dikenakan pajak berat, tetapi dapat meningkatkan tabungan atau investasi lain (Rahayu, 2017: 202).

Persepsi Wajib Pajak mengenai sanksi perpajakan adalah faktor penting dalam menentukan kepatuhan Wajib Pajak dalam memenuhi semua kewajiban pajakanya. Sejauh ini sanksi pajak digunakan untuk meningkatkan kepatuhan Wajib Pajak membayar pajaknya. Masyarakat pada umumnya patuh pada peraturan apabila ada sanksi yang mengikat. Semakin tinggi sanksi yang diberikan, maka menghasilkan kepatuhan yang semakin semakin baik.

Sikap Wajib Pajak merupakan pernyataan atau pertimbangan evaluatif, baik menguntungkan atau tak menguntungkan mengenai obyek, orang atau peristiwa. Sikap Wajib
Pajak mencerminkan bagaimana Sikap Wajib Pajak terhadap aspek lingkungan pajak baik sikapnya terhadap peraturan pajak, kebijakan pajak, adminitrasi pajak dan pelayanan pajak. Sikap yang baik dari Wajib Pajak meningkatkan kecenderungan kepatuhan dari Wajib Pajak (Heru, 2019: 264).

$\mathrm{H}_{5}$ : Pengaruh Moral Wajib Pajak, Penghindaran Pajak, Sanksi Perpajakan dan Sikap Wajib Pajak terhadap Kepatuhan Wajib Pajak Orang Pribadi

\section{METODE PENELITIAN}

Jenis Penelitian yang digunakan dalam penelitian ini adalah penelitian asosiatif. Data yang digunakan adalah data primer dan data sekunder. Populasi yang digunakan dalam penelitian ini adalah Wajib Pajak Orang Pribadi yang terdaftar sebanyak 62.694 di Kantor Pelayanan Pajak Pratama Palembang Seberang Ulu Tahun 2019. Sampel dalam penelitian ini sesuai dengan jumlah kuesioner yang dibagikan sebanyak 100 responden yang di dapat dari perhitungan menggunakan rumus Slovin.

Metode yang digunakan dalam penentuan sampel adalah menggunakan teknik simple random sampling. Metode pengumpulan data yang digunakan dalam penelitian ini adalah kuesioner dan dokumentasi. Teknik analisis yang digunakan adalah analisis kualitatif dan kuantitatif untuk mengetahui variabel bebas dengan variabel terikat digunakan uji asumsi klasik dan analisis regresi berganda.

\section{HASIL PENELITIAN}

Responden dalam penelitian ini berjumlah 100 Wajib Pajak Orang Pribadi. Variabel Moral Wajib Pajak $\left(\mathrm{X}_{1}\right)$ terdiri dari 6 pertanyaan, dari ke 6 
pertanyaan adalah valid ( $r$ hitung $>r$ tabel) dan dapat digunakan sebagai data penelitian. Variabel Penghindaran Pajak $\left(\mathrm{X}_{2}\right)$ terdiri dari 6 pertanyaan, dari ke 6 pertanyaan adalah valid $(r$ hitung $>r$ tabel) dan dapat digunakan sebagai data penelitian. Variabel Sanksi Perpajakan $\left(\mathrm{X}_{3}\right)$ terdiri dari 6 pertanyaan, dari ke 6 pertanyaan adalah valid ( $r$ hitung $>r$ tabel) dan dapat digunakan sebagai data penelitian. Variabel Sikap Wajib Pajak $\left(\mathrm{X}_{4}\right)$ terdiri dari 6 pertanyaan, dari ke 6 pertanyaan adalah valid ( $r$ hitung $>r$ tabel) dan dapat digunakan sebagai data penelitian. Variabel Kepatuhan Wajib Pajak Orang Pribadi (Y) terdiri dari 6 pertanyaan, dari ke 6 pertanyaan adalah valid ( $r$ hitung $>r$ tabel) dan dapat digunakan sebagai data penelitian. Variabel kontrol perilaku persepsian $\left(X_{5}\right)$ terdiri dari 6 pertanyaan, dari ke 6 pertanyaan adalah valid ( $r$ hitung $>r$ tabel) dan dapat digunakan sebagai data penelitian.

Nilai Cronbach Alpha Moral Wajib Pajak sebesar 0,676, Penghindaran Pajak sebesar 0,607, Sanksi Perpajakan sebesar 0,781, Sikap Wajib Pajak sebesar 0,768, dan Kepatuhan Wajib Pajak Orang Pribadi sebesar 0,774. Sehingga dapat disimpulkan bahwa pertanyaan dalam kuesioner semua variabel ini reliabel karena mempunyai Cronbach Alpha lebih dari 0,60.

\section{Uji Asumsi Klasik}

Uji Asumsi klasik yang digunakan dalam penelitian ini adalah sebagai berikut:

1. Uji Normalitas Data Hasil dari pengelolaan data, uji normalitas data dengan menggunakan SPSS Versi 22 adalah sebagai berikut:

\section{Gambar Hasil Uji Normalitas Metode Grafik}

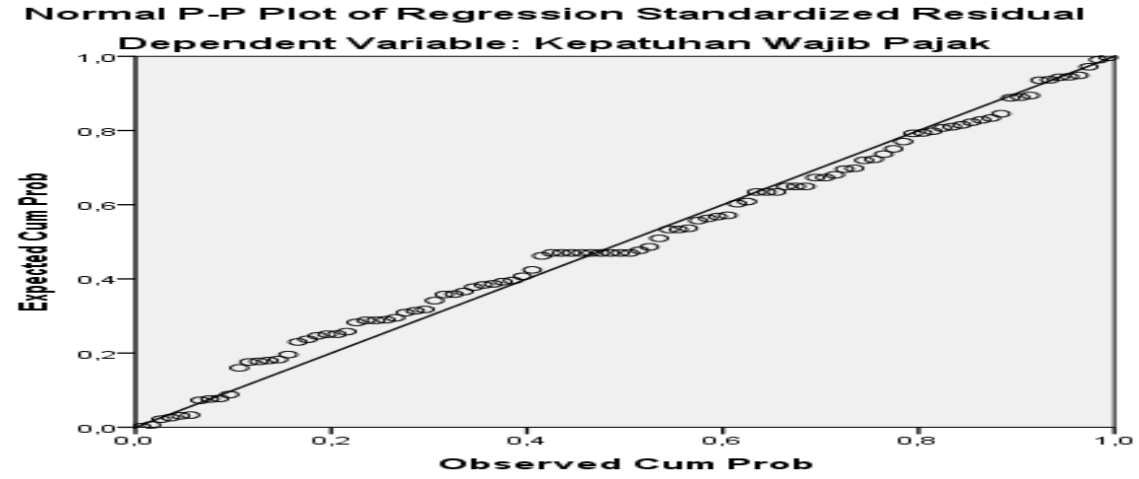

Sumber: Data Primer yang diolah (2020)

Berdasarkan gambar di atas titk-titik menyebar disekitar garis dan mengikuti garis diagonal, maka nilai residu tersebut normal.
2. Uji Multikolinearitas

Hasil dari pengelolaan data, uji multikolinearitas dengan menggunakan SPSS Versi 22 adalah sebagai berikut: 
Tabel Hasil Uji Multikolinearitas

\begin{tabular}{|c|c|c|c|c|c|c|c|}
\hline \multirow[b]{2}{*}{ Variable } & \multicolumn{2}{|c|}{$\begin{array}{c}\text { Unstandardized } \\
\text { Coefficients }\end{array}$} & \multirow{2}{*}{$\begin{array}{c}\text { Standardized } \\
\text { Coefficients } \\
\text { Beta }\end{array}$} & \multirow[b]{2}{*}{$\mathrm{T}$} & \multirow[b]{2}{*}{ Sig. } & \multicolumn{2}{|c|}{$\begin{array}{l}\text { Collinearity } \\
\text { Statistics }\end{array}$} \\
\hline & $B$ & Std. Error & & & & Tolerance & VIF \\
\hline 1 (Constant) & 1,890 & 2,607 & & ,725 & 470 & & \\
\hline Moral Wajib Pajak & 046 & 146 & 030 & , 316 & 753 & ,565 & 1,770 \\
\hline Penghindaran Pajak & 266 & 174 & 164 & 1,532 & 129 & 440 & 2,274 \\
\hline Sanksi Perpajakan & 411 & 162 & 295 & 2,538 & , 013 & 375 & 2,663 \\
\hline Sikap Wajib Pajak & ,458 & ,155 & ,325 & 2,949 & ,004 & ,416 & 2,406 \\
\hline
\end{tabular}

a. Dependent Variable: Kepatuhan Wajib Pajak

Sumber: Data Primer yang diolah (2020)

Berdasarkan tabel di atas menunjukkan semua variabel bebas mempunyai nilai tolerance $>0,1$ dari nilai VIF < 10 dengan demikian, maka disimpulkan bahwa seluruh variabel bebas dalam penelitian ini tidak terjadi multikolineritas.
3. Uji Heteroskedastisitas

Hasil dari pengelolaan data, uji heteroskesastisitas dengan menggunakan program SPSS Versi 22 adalah sebagai berikut: Pengujian heteroskedastisitas didukung dengan analisis statistik menggunakan metode uji glesjer.

Tabel Hasil Uji Heteroskedastisitas Metode Glesjer

Coefficients $^{\mathrm{a}}$

\begin{tabular}{|c|c|c|c|c|c|c|c|}
\hline \multirow[b]{2}{*}{ Variable } & \multicolumn{2}{|c|}{$\begin{array}{c}\text { Unstandardized } \\
\text { Coefficients }\end{array}$} & \multirow{2}{*}{$\begin{array}{c}\text { Standardized } \\
\text { Coefficients }\end{array}$} & \multirow[b]{2}{*}{$\mathrm{t}$} & \multirow[b]{2}{*}{ Sig. } & \multicolumn{2}{|c|}{ Collinearity Statistics } \\
\hline & $B$ & Std. Error & & & & Tolerance & VIF \\
\hline 1 (Constant) & 2,443 & 1,692 & & 1,443 & ,152 & & \\
\hline $\begin{array}{l}\text { Moral Wajib } \\
\text { Pajak }\end{array}$ & 011 & 095 &, 016 & , 116 & ,908 &, 565 & 1,770 \\
\hline $\begin{array}{l}\text { Penghindaran } \\
\text { Pajak }\end{array}$ &,- 027 & 113 &,- 037 &,- 240 & - 811 & ,440 & 2,274 \\
\hline $\begin{array}{l}\text { Sanksi } \\
\text { Perpajakan }\end{array}$ & - 101 & 105 & -159 &,- 957 & ,341 & 375 & 2,663 \\
\hline $\begin{array}{l}\text { Sikap Wajib } \\
\text { Pajak }\end{array}$ & 121 & 101 & , 189 & 1,200 & 233 & ,416 & 2,406 \\
\hline
\end{tabular}

a. Dependent Variable: Res2

Sumber: Data Primer yang diolah (2020)

Berdasarkan tabel diatas menunjukkan bahwa semua variabel bebas mempunyai nilai probabilitas lebih besar dari 0,05. Dengan demikian, hal ini dapat disimpulkan bahwa tidak terjadi heteroskedastisitas.

\section{Koefisien Determinasi}

Uji ini untuk menentukan proporsi atau persentase total variasi dalam variabel terikat yang diterangkan oleh variabel bebas. Hasil perhitungan Adjusted $R_{2}$ dapat dilihat pada output model summary. Pada kolom Adjusted $R_{2}$ dapat diketahui berupa persentase yang dapat dijelaskan oleh variabelvariabel bebas terhadap variabel terikat. Sedangkan sisanya dipengaruhi atau dijelaskan oleh 
variabel-variabel lain yang tidak dimasukkan dalam model penelitian.

Tabel Hasil Koefisien Determinasi $\left(\mathbf{R}^{2}\right)$

\begin{tabular}{|l|c|r|r|r|}
\hline Variable & $\mathrm{R}$ & $\mathrm{R}$ Square & Adjusted R Square & Std. Error of the Estimate \\
\hline 1 &, $721^{\mathrm{a}}$ &, 519 &, 499 & 3,455 \\
\hline
\end{tabular}

a. Predictors: (Constant), Sikap Wajib Pajak, Moral Wajib Pajak, Penghindaran Pajak, Sanksi

Perpajakan

b. Dependent Variable: Kepatuhan Wajib Pajak

Sumber: Data Primer yang diolah (2020)

Berdasarkan tabel hasil uji hipotesis tabel Model Summary diperoleh nilai $\mathrm{R}$ Square $\left(R^{2}\right)$ sebesar 0,519 . Nilai menunjukkan bahwa variabel dipengaruhi $52 \%$. Hal ini berarti $52 \%$ variabel Moral Wajib Pajak $\left(X_{1}\right)$, Penghindaran Pajak $\left(X_{2}\right)$, Sanksi Perpajakan $\left(X_{3}\right)$ dan Sikap Wajib Pajak $\left(X_{4}\right)$ sedangkan sisanya $48 \%$ dipengaruhi oleh faktor lain seperti kualitas seperti kualitas pelayanan, pemahaman perpajakan, E-filling dan E-Billing dan faktor-faktor lain yang diduga berpengaruh terhadap Kepatuhan Wajib Pajak Orang Pribadi.

\section{Uji Hipotesis}

1) Pengujian hipotesis secara parsial/individual

Untuk menjawab:
$\mathrm{H}_{01}$ : Moral Wajib Pajak tidak berpengaruh terhadap Kepatuhan Wajib Pajak Orang Pribadi

$\mathrm{H}_{02}$ : Penghindaran Pajak tidak berpengaruh terhadap Kepatuhan Wajib Pajak Orang Pribadi

$\mathrm{H}_{\mathrm{a} 3}$ : Sanksi berpengaruh terhadap Kepatuhan Wajib Pajak Orang Pribadi

$\mathrm{H}_{\mathrm{a} 4}$ : Sikap Wajib Pajak berpengaruh terhadap Kepatuhan Wajib Pajak Orang pribadi

Maka hasilnya diuji dengan menggunakan uji t, dapat dilihat pada tabel berikut:

Tabel Hasil Uji Parsial

Coefficients $^{a}$

\begin{tabular}{|c|c|c|c|c|c|}
\hline \multirow[b]{2}{*}{ Variable } & \multicolumn{2}{|c|}{$\begin{array}{l}\text { Unstandardized } \\
\text { Coefficients }\end{array}$} & \multirow{2}{*}{$\begin{array}{c}\begin{array}{c}\text { Standardized } \\
\text { Coefficients }\end{array} \\
\text { Beta }\end{array}$} & \multirow[b]{2}{*}{$\mathrm{T}$} & \multirow[b]{2}{*}{ Sig. } \\
\hline & B & Std. Error & & & \\
\hline 1 (Constant) & 1,890 & 2,607 & & ,725 & 470 \\
\hline Moral Wajib Pajak & ,046 & 146 & ,030 & ,316 & 753 \\
\hline $\begin{array}{l}\text { Penghindaran } \\
\text { Pajak }\end{array}$ & ,266 & 174 & 164 & 1,532 & 129 \\
\hline $\begin{array}{l}\text { Sanksi } \\
\text { Perpajakan }\end{array}$ & ,411 & 162 & 295 & 2,538 & 013 \\
\hline Sikap Wajib Pajak & ,458 &, 155 & ,325 & 2,949 &, 004 \\
\hline
\end{tabular}

a. Dependent Variable: Kepatuhan Wajib Pajak

Sumber: Data Primer yang diolah (2020) 


\section{$\mathrm{H}_{01}$ : Moral Wajib Pajak tidak berpengaruh terhadap Kepatuhan Wajib Pajak}

Berdasarkan tabel di atas menunjukkan nilai tabel dengan taraf nyata (a) sebesar $5 \%(0,05)$ serta $\mathrm{db}$ $(\mathrm{n}-\mathrm{k}-1)=(95)=1.985$

Hasil uji hipotesis menunjukkan bahwa diketahui nilai signifikan $(0,753)$ dengan menggunakan tabel dengan taraf nyata df, maka thitung $0,316<$ 1.985 dan signifikan Moral Wajib Pajak sebesar $0,753>0,05$. Jadi dapat disimpulkan bahwa $\mathrm{H}_{02 a}$ diterima dan $\mathrm{H}_{\mathrm{a} 2 \mathrm{a}}$ ditolak. Hal ini menunjukkan Moral Wajib Pajak tidak berpengaruh secara parsial terhadap Kepatuhan Wajib Pajak Orang Pribadi.

\section{$\mathrm{H}_{02}$ : Penghindaran Pajak tidak berpengaruh terhadap Kepatuhan Wajib Pajak}

Berdasarkan tabel di atas menunjukkan nilai t tabel dengan taraf nyata (a) sebesar $5 \%(0,05)$ serta $\mathrm{db}$ $(n-k-1)=(95)=1.985$

Hasil uji hipotesis mnunjukkan bahwa diketahui nilai signifikan $(0,129)$ dengan menggunakan tabel dengan taraf nyata df, maka thitung 1.532 < 1.985 dan signifikan Penghindaran Pajak sebesar 0,129>0,05. Jadi dapat disimpulkan bahwa $\mathrm{H}_{02 a}$ diterima dan $\mathrm{H}_{\mathrm{a} 2 \mathrm{a}}$ ditolak. Hal ini menunjukkan Penghindaran Pajak tidak berpengaruh secara parsial terhadap Kepatuhan Wajib Pajak Orang Pribadi.

\section{$\mathrm{H}_{\mathrm{a} 3}$ : Sanksi Perpajakan berpengaruh terhadap Kepatuhan Wajib Pajak}

Hasil uji hipotesis menunjukkan bahwa diketahui nilai signifikan variabel Sanksi Perpajakan terhadap Kepatuhan Wajib Pajak sebesar 0,013 dengan menggunakan tabel dengan taraf nyata df, maka thitung $2.538>$ 1,985 dan signifikan Sanksi
Perpajakan $0,013<0,05$. Jadi dapat disimpulkan bahwa $\mathrm{H}_{\mathrm{a} 2 \mathrm{c}}$ diterima dan $\mathrm{H}_{02 \mathrm{c}}$ ditolak. Hal ini menunjukkan bahwa Sanksi Perpajakan berpengaruh secara parsial terhadap Kepatuhan Wajib Pajak Orang Pribadi. Hasil penelitian ini Sanksi Perpajakan secara signifikan mempengaruhi Kepatuhan Wajib Pajak Orang Pribadi melalui Indikator:

1. Sanksi yang tegas

2. Sanksi perpajakan memotivasi Wajib Pajak untuk patuh

3. Sosialisasi sanksi perpajakan

\section{$H_{a 4}$ : Sikap Wajib Pajak berpengaruh} terhadap Kepatuhan Wajib Pajak

Hasil uji hipotesis menunjukkan bahwa diketahui nilai signifiakan varabel Sikap Wajib Pajak terhadap Kepatuhan Wajib Pajak sebesar 0,04 dengan menggunakan tabel dengan taraf nyata df, maka thitung 2.949 > 1.985 dan signifikan Sikap Wajib Pajak $0,04<0,05$. Jadi dapat disimpulkan bahwa $\mathrm{H}_{\mathrm{a} 2 \mathrm{~d}}$ diterima dan $\mathrm{H}_{02 \mathrm{~d}}$ ditolak. Hal ini menunjukkan bahwa Sikap Wajib Pajak berpengaruh secara parsial terhadap Kepatuhan Wajib Pajak Orang Pribadi.

Hasil penelitian ini Sikap Wajib Pajak secara signifikan mempengaruhi Kepatuhan Wajib Pajak Orang Pribadi melalui indikator:

1. Aspek Ekonomi

2. Aspek Regulasi Pemerintahan

3. Aspek Birokrasi

\section{2) Pengujian Hipotesis Secara Simultan/Bersama-sama \\ Uji F dilakukan untuk mengetahui} adalah pengaruh variabel independen Moral Wajib Pajak, Penghindaran Pajak, Sanksi Perpajakan, dan Sikap Wajib Pajak terhadap Kepatuhan Wajib Pajak secara bersama-sama atau simultan. 


\section{Tabel Hasil Uji Secara Simultan}

\begin{tabular}{|c|c|c|c|c|c|}
\hline \multicolumn{6}{|c|}{ ANOVA $^{a}$} \\
\hline Model & $\begin{array}{c}\text { Sum of } \\
\text { Squares }\end{array}$ & Df & $\begin{array}{l}\text { Mean } \\
\text { Square }\end{array}$ & $\mathrm{F}$ & Sig. \\
\hline $1 \quad$ Regression & 1226,230 & 4 & 306,558 & 25,676 &, $000^{b}$ \\
\hline Residual & 1134,252 & 95 & 11,939 & & \\
\hline Total & 2360,482 & 99 & & & \\
\hline
\end{tabular}

a. Dependent Variable: Kepatuhan Wajib Pajak

b. Predictors: (Constant), Sikap Wajib Pajak, Moral Wajib Pajak, Penghindaran Pajak, Sanksi Perpajakan

Sumber: Data Primer yang diolah (2020)

Berdasarkan tabel di atas menunjukkan nilai $F_{\text {tabel }}$ dengan taraf nyata (a) sebesar $5 \%(0,05)$ serta $(d b)$ $=(\mathrm{k} ; \mathrm{n}-\mathrm{k})=\mathrm{F}(4 ; 96)=2,47$

Berdasarkan tabel dijelaskan nilai signifikan $\mathrm{F}$ menunjukkan bahwa $F_{\text {hitung }}$ sebesar $25.675>F_{\text {tabel }} 2,47$ dengan tingkat signifikan 0,000 lebih kecil dari 0,05 . Hal ini menunjukkan bahwa Moral Wajib Pajak $\left(X_{1}\right)$, Penghindaran Pajak $\left(X_{2}\right)$, Sanksi Perpajakan $\left(X_{3}\right)$ dan Sikap Wajib Pajak terhadap Kepatuhan Wajib Pajak Orang Pribadi (Y).

\section{E. PEMBAHASAN}

1. Moral Wajib Pajak terhadap Kepatuhan Wajib Pajak Orang Pribadi

Ho1: Moral Wajib Pajak tidak
berpengaruh terhadap
Kepatuhan Wajib Pajak
Orang Pribadi

Berdasarkan analisis dengan menggunakan SPSS Versi 22 dan uji hipotesis yang dilakukan bahwa $\mathrm{H}_{01}$ diterima dan $\mathrm{H}_{\mathrm{a} 1}$ ditolak. Artinya Moral Wajib pajak tidak berpengaruh terhadap Kepatuhan Wajib Pajak Orang Pribadi. Hal ini dapat dibuktikan dengan $t_{\text {hitung }}$ lebih kecil dari $t_{\text {tabel }}$ dan nilai signifikan lebih besar dari nilai alpha. Hal ini menunjukkan bahwa semakin rendah Moral Wajib Pajak, maka tingkat Kepatuhan Wajib Pajak Orang Pribadi semakin menurun.
Moral adalah integritas dan martabat pribadi yang dimiliki manusia. Moral berkaitan dengan nilai baik dan buruk perbuatan manusia. Tindakan yang bermoral adalah tindakan manusia yang dilakukan secara sadar, mau atau tahu serta tindakan yang berjunjung tinggi nilai pribadi manusia, harkat dan martabat manusia. Kepatuhan Wajib Pajak lebih jika moral penduduk baik. Keinginan untuk meloloskan diri dari pajak lebih termotivasi dengan kondisi moral masyarakat yang rendah. Moral masyarakat yang buruk menghambat pemungutan pajak, ketidakpatuhan mendominasi kewajiban perpajakan Wajib Pajak.

Hasil penelitian tidak sejalan dengan Theory of moral reasoning adalah teori yang menyatakan keputusan moral terutama yang dipengaruhi oleh perlakuan terhadap sanksi pada tingkatan moral reasoning yang rendah, pengharapan adanya keadilan (peer expectation) pada tingkatan yang tertinggi. Wajib Pajak yang lebih menggunakan prinsip moral dalam pengambilan keputusan pembayaran pajak lebih patuh dibandingkan Wajib Pajak lainnya. Wajib Pajak dengan tingkatan moral yang sama tetapi memiliki persepsi yang berbeda akan memilki reaksi yang berbeda terhadap kepatuhan pajak. 


\section{Penghindaran Pajak terhadap Kepatuhan Wajib Pajak \\ Ho2: Penghindaran Pajak tidak berpengaruh terhadap Kepatuhan Wajib Pajak}

Berdasarkan analisis dengan menggunakan SPSS Versi 22 dan uji hipotesis yang dilakukan bahwa $\mathrm{H}_{02}$ diterima dan $\mathrm{H}_{\mathrm{a} 2}$ ditolak. Artinya Penghindaran Pajak tidak berpengaruh terhadap Kepatuhan Wajib Pajak Orang Pribadi. Hasil ini dapat dibuktikan dengan thitung kecil dari tabel dan nilai signifikan lebih besar dari nilai alpha. Hal ini menunjukkan bahwa semakin tinggi Penghindaran Pajak, maka tingkat Kepatuhan Wajib Pajak Orang Pribadi semakin rendah.

Penghindaran Pajak merupakan tindakan dalam meminimalkan beban pajak dengan usaha Wajib Pajak yang tidak melanggar norma peraturan perundang-undangan perpajakan. Hasil penelitian menunjukkan bahwa Penghindaran Pajak yang dilakukan oleh responden cukup baik, terbukti bahwa dengan mayoritas responden mengisi poin setuju pada masingmasing pertanyaan. Hal ini menunjukkan bahwa reponden merasa Penghindaran Pajak belum berjala dengan baik. Karena itu responden cukup sulit untuk memenuhi kewajiban perpajakan dan merasa takut sehingga meraka tidak patuh dalam memenuhi semua kewajiban perpajakannya.

Hasil penelitian ini tidak sejalan dengan teori ekuitas Teori ini menyangkut aspek hak dan kewajiban Wajib Pajak. Apabila Wajib Pajak memandang bahwa hak dan kewajibannya sebanding dengan artian bahwa adanya keseimbangan antara kewajibannya sebagai Wajib Pajak dan hak-hak yang dapat diperolehnya, maka Wajib Pajak cenderung lebih patuh dalam menjalankan kewajiban pajaknya. Teori ini juga menyangkut keadilan dalam perlakuan terhadap setiap Wajib Pajak.

\section{Pengaruh Sanksi Perpajakan terhadap Kepatuhan Wajib Pajak Orang Pribadi}

Haz: Sanksi Perpajakan

berpengaruh terhadap Kepatuhan

Wajib Pajak Orang Pribadi

Berdasarkan analisis dengan menggunakan SPSS Versi 22 dan uji hipotesis yang dilakukan bahwa $\mathrm{H}_{\mathrm{a}}$ diteima dan $\mathrm{H}_{03}$ ditolak. Artinya Sanksi Perpajakan berpengaruh terhadap Kepatuhan Wajib Pajak Orang Pribadi. Hasil ini dapat dibuktikan dengan nilai thitung lebih besar dari tabel dan nilai signifikan lebih kecil dari nilai alpha. Hal ini menunjukkan bahwa semakin tinggi Sanksi Perpajakan, maka tingkat Kepatuhan Wajib Pajak Orang Pribadi semakin baik.

Sanksi Perpajakan merupakan salah satu upaya pemerintah untuk meningkatkan kepatuhan Wajib Pajak akan tanggung jawab perpajakannya. Sanksi perpajakan terdiri dari sanksi berupa bunga, denda dan kenaikan. Wajib Pajak yang tidak ingin dikenai sanksi tersebut harus semaksimal mungkin untuk meningkatkan kepatuhan Wajib Pajak dalam hal perpajakan.

Hasil penelitian ini sejalan dengan teori ekuitas. Teori ini menyangkut aspek hak dan kewajiban Wajib Pajak. Apabila Wajib Pajak memandang bahwa hak dan kewajibannya sebanding dengan artian bahwa adanya keseimbangan antara kewajibannya sebagai Wajib Pajak dan hak-hak yang dapat diperolehnya, maka Wajib Pajak cenderung lebih patuh dalam menjalankan kewajiban pajaknya. Teori ini juga menyangkut keadilan dalam perlakuan terhadap setiap Wajib Pajak. 


\section{Pengaruh Sikap Wajib Pajak terhadap Kepatuhan Wajib Pajak Orang Pribadi \\ $H_{a 4}$ : Sikap Wajib Pajak} berpengaruh terhadap Kepatuhan Wajib Pajak

Berdasarkan analisis dengan menggunakan SPSS Versi 22 dan uji hipotesis yang dilakukan bahwa $\mathrm{H}_{\mathrm{a} 4}$ diterima dan $\mathrm{H}_{04}$ ditolak. Artinya Sikap Wajib Pajak berpengaruh terhadap Kepatuhan Wajib Pajak Orang Pribadi. Hasil ini dapat dibuktikan dengan nilai $t_{\text {hitung }}$ lebih besar dari $t_{\text {tabel }}$ dan nilai signifikan dari nilai alpha. Hal ini menunjukkan bahwa semakin baik Sikap Wajib Pajak, maka semakin tinggi juga Kepatuhan Wajib Pajak Orang Pribadi.

Sikap merupakan kecenderungan pernyataan seseorang, baik menyenangkan maupun tidak meyenangkan, yang mencerminkan bagaimana merasa tentang orang, objek atau kejadian di dalam lingkungannya. Sikap Wajib Pajak yang patuh adalah Wajib Pajak yang sadar, paham hak dan kewajiban perpajakan dan diharapkan peduli terhadap pajak yaitu melaksanakan kewajiban perpajakannya dengan benar dan paham hak perpajakannya. Sedangkan jika Wajib Pajak tidak patuh maka menimbulkan keinginan untuk melakukan penghindaran, pengelakan, penyelundupan dan pelalaian pajak. Pada akhirnya tindakan tersebut menyebabkan penerimaan negara berkurang.

Hasil penelitian ini sejalan dengan teori ekuitas yang menekankan pada aspek keadilan. Teori ini menyamgkut aspek hak dan kewajiban Wajib Pajak. Apabila Wajib Pajak memandang bahwa hak dan kewajibannya sebanding dengan artian bahwa adanya keseimbangan antara kewajibannya sebagai Wajib Pajak dak hak-hak yang dapat diperolehnya, maka Wajib Pajak cenderung lebih patuh dalam menjalankan kewajiban pajaknya.

\section{Pengaruh Moral Wajib Pajak, Penghindaran Pajak, Sanksi Perpajakan dan Sikap Wajib Pajak terhadap Kepatuhan Wajib Pajak Orang Pribadi}

Ha5: Moral Wajib Pajak, Penghindaran Pajak, Sanksi Perpajakan dan Sikap Wajib Pajak berpengaruh terhadap Kepatuhan Wajib Pajak Orang Pribadi

Berdasarkan analisis dengan menggunakan SPSS Versi 22 dan uji hipotesis yang dilakukan bahwa $\mathrm{H}_{\mathrm{a}}$ diterima artinya Moral Wajib Pajak, Penghindaran Pajak, Sanksi Perpajakan dan Sikap Wajib Pajak berpengaruh terhadap Kepatuhan Wajib Pajak Orang Pribadi. Hasil ini dapat dibuktikan dengan nilai $F_{\text {hitung }}$ lebih besar dari $F_{\text {tabel. }}$ Hal ini menunjukkan bahwa semakin baik Moral Wajib Pajak, Penghindaran Pajak, Sanksi Perpajakan dan Sikap wajib Pajak terhadap Kepatuhan Wajib pajak Orang Pribadi.

Moral Wajib Pajak, Penghindaran Pajak, Sanksi Perpajakan, dan Sikap Wajib Pajak merupakan salah satu indikator yang penting dimiliki oleh setiap Wajib Pajak dalam meningkatkan Kepatuhan Wajib Pajak Orang Pribadi. Dari hasil penelitian ini menunjukkan bahwa Kepatuhan Wajib Pajak Orang Pribadi yang terdaftar di KPP Pratama Palembang Seberang Ulu membutuhkan Moral Wajib Pajak, Penghindaran Pajak, Sanksi Perpajakan dan Sikap Wajib Pajak untuk meningkatkan Kepatuhan Wajib Pajak Orang Pribadi dengan melaksanakan hak dan kewajiban perpajakan sesuai dengan peraturan perpajakan yang berlaku. 
Hal ini sejalan dengan teori ekuitas yang menekankan pada aspek keadilan. Teori ini menyangkut aspek hak dan kewajiban Wajib Pajak. Apabila Wajib Pajak memandang bahwa hak dan kewajibannya sebanding dengan artian bahwa adanya keseimbangan antara kewajibannya sebagai Wajib Pajak dan hak-hak yang dapat diperolehnya, maka Wajib Pajak cenderung lebih patuh dalam menjalankan kewajiban pajaknya. Teori ini juga menyangkut keadilan dalam perlakuan terhadap setiap Wajib Pajak.

\section{F. KESIMPULAN DAN SARAN}

1) Kesimpulan

Berdasarkan hasil penelitian dan pembahasan, maka dapat diambil kesimpulan sebagai berikut:

a. Moral Wajib Pajak tidak berpengaruh terhadap Kepatuhan Wajib Pajak Orang Pribadi. Hal ini ditunjukkan bahwa semakin rendah Moral Wajib Pajak, maka tingkat Kepatuhan Wajib Pajak Orang Pribadi semakin menurun.

b. Penghindaran Pajak tidak berpengaruh terhadap Kepatuhan Wajib Pajak Orang Pribadi. Hal ini ditujukkan bahwa semakin tinggi Penghindaran Pajak, maka tingkat Kepatuhan Wajib Pajak Orang Pribadi semakin rendah.

c. Sanksi Perpajakan berpengaruh terhadap Kepatuhan Wajib Pajak Orang Pribadi. Hal ini ditunjukkan bahwa semakin tinggi Sanksi Perpajakan, maka tingkat Kepatuhan Wajib Pajak Orang Pribadi semakin baik.

d. Sikap Wajib Pajak berpengaruh terhadap Kepatuhan Wajib Pajak Orang Pribadi. Hal ini ditunjukkan bahwa semakin baik Sikap Wajib Pajak, maka semakin tinggi juga Kepatuhan Wajib Pajak Orang Pribadi. e. Moral Wajib Pajak, Penghindaran Pajak, Sanksi Perpajakan dan Sikap Wajib Pajak berpengaruh terhadap Kepatuhan Wajib Pajak Orang Pribadi. Hal ini ditunjukkan bahwa semakin baik Moral Wajib Pajak, Penghindaran Pajak, Sanksi Perpajakan dan Sikap Wajib Pajak, maka semakin tinggi juga tingkat Kepatuhan Wajib Pajak Orang Pribadi.

\section{2) Saran}

Berdasarkan kesimpulan, maka diberikan saran sebagai berikut:

a. Wajib Pajak hendaklah memilki moral yang baik dalam memiliki NPWP dan jujur dalam melaporkan SPT.

b. Wajib Pajak hendaklah taat dalam membayar pajak sehingga terhindar dari sanksi perpajakan.

c. Wajib Pajak hendaklah menaati semua peraturan perpajakan yang berlaku.

d. Wajib Pajak hendaklah tepat waktu dalam memenuhi semua kewajiban perpajakan dan hak perpajakannya.

e. Wajib Pajak hendaklah memilki moral yang baik dalam memperoleh NPWP, jujur dalam melaporkan SPT, taat dalam membayar pajak, menaati semua peraturan perpajakan yang berlaku dan tepat waktu dalam memenuhi semua kewajiban perpajakan dan hak perpajakannya.

\section{DAFTAR PUSTAKA}

Heru, K. (2019). Pengantar Perpajakan Cara Meningkatkan Kepatuhan Pajak. Surabaya: Indeks Jakarta.

Mardiasmo. (2016). Perpajakan Edisi Revisi. Yogyakarta: Andi offset. 
Rahayu, S. K. (2017). Konsep dan Aspek Formal Perpajakan. Yogyakarta: Graha IImu.

Resmi, S. (2017). Perpajakan Teori dan Kasus. Yogyakarta: Salemba Empat.
Republik Indonesia. (2009). Undangundang No. 16 Tahun 2009 tentang Ketentuan Umum dan Tata Cara Perpajakan. 